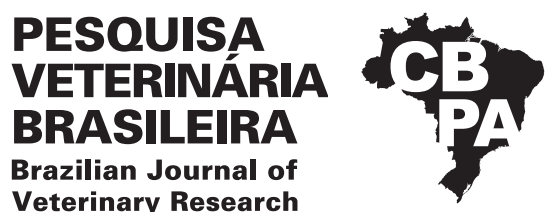

Pesq. Vet. Bras. 41:e06557, 2021

DOI: 10.1590/1678-5150-PVB-6757

Original Article

Veterinarv Research

ISSN 0100-736X (Print)

ISSN 1678-5150 (Online)

\title{
Evaluation of hip joint laxity in crab-eating foxes (Cerdocyon thous) ${ }^{1}$
}

\author{
Maíra S. Castilho²* (D), Sheila C. Rahal², Maria J. Mamprim², Letícia R. Inamassu², \\ Ramiro N. Dias Neto ${ }^{2}$, Alessandra Melchert ${ }^{3}$, Lídia M. Matsubara ${ }^{2}$ \\ and Luciane R. Mesquita ${ }^{2 *}$ (D)
}

\begin{abstract}
Castilho M.S., Rahal S.C, Mamprim M.J., Inamassu L.R., Dias Neto R.N., Melchert A., Matsubara L.M. \& Mesquita L.R. 2021. Evaluation of hip joint laxity in crab-eating foxes (Cerdocyon thous). Pesquisa Veterinária Brasileira 41:e06757, 2021. Faculdade de Medicina Veterinária e Zootecnia, Universidade Estadual Paulista "Júlio de Mesquita Filho", Distrito de Rubião Júnior, Botucatu, SP 18618-970, Brazil. E-mail: lrmesquita@yahoo.com.br

Like canids, crab-eating foxes may probably be predisposed to similar orthopedic diseases of domestic dogs, such as hip dysplasia. However, for the adequate hip dysplasia diagnosis in wild animals, the normality characteristics of each species must be determined. This study aimed to estimate radiographic and computed tomographic (CT) values of hip joint laxity in healthy crab-eating foxes. Fifteen intact crab-eating foxes, eight males and seven females, ages 1 to 5 and mean body mass of 6.66kg were used. Norberg angle (NA) was calculated from ventrodorsal hip-extended radiographs. To calculate the dorsolateral subluxation (DLS) score, the center distance (CD) index, the lateral center edge angle (LCEA), and the dorsal acetabular rim angle (DARA), measurements obtained from transverse CT images were used. No statistically significant differences were observed between the right and left sides in the radiographic and tomographic parameters. The mean NA was $107.57^{\circ}$. The mean DLS score, the CD index, the LCEA, and the DARA were $60.79 \%, 0.16,98.25^{\circ}$ and $13.47^{\circ}$, respectively. The data obtained are helpful in characterizing mean values of the hip joint in healthy crabeating foxes, and can contribute to the knowledge of the species.
\end{abstract}

INDEX TERMS: Hip joint, laxity, crab-eating foxes, Cerdocyon thous, radiography, computed tomography, wildlife animals.

'RESUMO.- [Avaliação da lassitude da articulação coxofemoral em cachorro-do-mato (Cerdocyon thous).] Como canídeos, os cachorros-do-mato podem estar predispostos a doenças ortopédicas semelhantes aquelas de cães domésticos, tais como a displasia coxofemoral. No entanto, para o diagnóstico adequado da displasia coxofemoral em animais selvagens, os padrões de normalidade de cada espécie precisam ser determinados. Sendo assim, o presente estudo teve como objetivo estimar os valores radiográficos e tomográficos (TC) da lassitude da articulação coxofemoral em cachorros-do-

\footnotetext{
${ }^{1}$ Received on September 16, 2020.

Accepted for publication on November 12, 2020.

${ }^{2}$ Departamento de Cirurgia Veterinária e Reprodução Animal, Faculdade de Medicina Veterinária e Zootecnia (FMVZ), Universidade Estadual Paulista "Júlio de Mesquita Filho" (Unesp), Distrito de Rubião Júnior, Botucatu, SP 18618-970, Brazil. *Corresponding author: maira165@gmail.com, lrmesquita@yahoo.com.br

${ }^{3}$ Departmento de Clínica Veterinária, Faculdade de Medicina Veterinária e Zootecnia (FMVZ), Universidade Estadual Paulista "Júlio de Mesquita Filho" (Unesp), Distrito de Rubião Júnior, Botucatu, SP 18618-970, Brazil.
}

mato hígidos. Foram utilizados quinze cachorros-do-mato não castrados, oito machos e sete fêmeas, com idades entre 1 e 5 anos e massa corporal média de 6,66kg. 0 ângulo de Norberg (NA) foi calculado a partir de radiografias na projeção ventrodorsal com os membros estendidos. Para calcular o escore de subluxação dorsolateral (DLS), o índice de distância central (CD), o ângulo da margem central lateral (LCEA) e o ângulo da borda dorsal acetabular (DARA), foram utilizadas as mensurações obtidas a partir de imagens transversais da TC. Não foram observadas diferenças estatísticas entre os lados direito e esquerdo nos parâmetros radiográficos e tomográficos. A média do NA foi de $107,57^{\circ}$. As médias do escore do DLS, do índice de CD, e dos ângulos LCEA e DARA foram, respectivamente, $60,79 \%, 0,16,98,25^{\circ}$ e $13,47^{\circ}$. Os dados obtidos são úteis para a caracterização dos valores médios referentes à articulação coxofemoral de cachorrosdo-mato e podem contribuir para o conhecimento da espécie.

TERMOS DE INDEXAÇÃO: Lassitude, articulação coxofemoral, cachorro-do-mato, Cerdocyon thous, radiografia, tomografia computadorizada, animais selvagens. 


\section{INTRODUCTION}

Crab-eating foxes (Cerdocyon thous) have a general pattern of grayish hair on the back; reddish face, ears and legs; whitish throat and belly; black-tipped ears and tail; and black on the back of the legs (Berta 1982, Ginsberg \& MacDonald 1990). However, within this pattern can occur a great variation among individuals (Berta 1982). The crab-eating fox is a monogamous animal that lives in extended family groups or in couples (Ginsberg \& MacDonald 1990, Beisiegel et al. 2013). The activity pattern is mainly nocturnal and crepuscular (Cheida et al. 2006).

In relation to diet and habitat, the species is considered to be generalist and flexible (Beisiegel et al. 2013). Therefore, the species has the ability to occupy diverse habitats, such as savannahs, marshlands, caatingas, and forests (Beisiegel et al. 2013, Lucherini 2015). In addition, crab-eating foxes have adapted to deforestation, areas of agricultural and horticultural development, as well as habitats in regeneration (Lucherini 2015). The short and robust limbs facilitate the locomotion in dense forests (Berta 1982).

Like canids, crab-eating foxes may probably be predisposed to similar orthopedic diseases of domestic dogs, such as hip dysplasia. In domestic dogs the hip dysplasia is characterized by coxofemoral joint laxity, degeneration and osteoarthritis, considered a developmental disorder and multifactorial, containing a hereditary component (Vezzoni 2007, Schachner \& Lopez 2015). In most cases, there is acetabular dysplasia and femoral dysplasia, the latter evidenced by alterations in length, inclination and anteversion of the femoral neck (Vezzoni 2007). The disease has a high prevalence in large dogs, brachycephalic dogs and those with a high proportion of body length and height (Vezzoni 2007, Schachner \& Lopez 2015). In wild animals, the disease has occasionally been reported, such as in a timber wolf (Douglass 1981).

There are several protocols for determination of hip dysplasia in domestic dogs, including static radiographic studies of ventrodorsal hip-extended view with the animal deeply sedated or anesthetized (Vezzoni 2007, Flückiger 2007a, Verhoeven et al. 2012, Dennis 2012). Radiographic scoring methods are used for the assessment of the severity of the bone changes in the ventrodorsal hip-extended view, but score differences are observed between countries and entities (Flückiger 2007b, Dennis 2012). Other imaging modalities such as computed tomography (CT) and magnetic resonance imaging are still not commonly used (Farese et al. 1998, Todhunter et al. 2003, Fujiki et al. 2004, Kishimoto et al. 2009).

However, for the adequate hip dysplasia diagnosis in wild animals, the normality characteristics of each species must be determined. Therefore, the aim of this study was to estimate radiographic and CT values of hip joint laxity in healthy crab-eating foxes.

\section{MATERIALS AND METHODS}

The study was approved by the Ethics Committee of the "Faculdade de Medicina Veterinária e Zootecnia”, Unesp Botucatu (no. 194/2014 - CEUA), and by the National Environmental and Wildlife Bureau (SISBIO - 47049).

Fifteen skeletally mature crab-eating foxes (Cerdocyon thous), eight intact males and seven intact females, ages 1 to 5 , weighing from 5.5 to $7.9 \mathrm{~kg}$ (mean $\pm \mathrm{SD}=6.66 \pm 0.79 \mathrm{~kg}$ ) were used. The animals belong to Medical and Research Center in Wildlife (CEMPAS), or Municipal Zoological Park "Quinzinho de Barros" (Category A zoo). They were considered to be healthy, based on the results of physical and orthopedic examinations (visual gait analysis; hip joint palpation; coxofemoral range of motion in flexion/extension and abduction/ adduction; and Ortolani test), and radiographs of the limbs.

For imaging studies, the crab-eating foxes were initially premedicated with ketamine $(8 \mathrm{mg} / \mathrm{kg})$ and midazolam $(0.3 \mathrm{mg} / \mathrm{kg})$ administered intramuscularly. After 15 minutes, general anesthesia was induced with propofol $(5 \mathrm{mg} / \mathrm{kg} / \mathrm{IV}$ ) to allow endotracheal intubation. Anesthesia was maintained with isoflurane in 100\% oxygen (stage III, planes 2-3) using rebreathing circuit system (Conquest 2003, HB Hospitalar Ind. Com., São Paulo, Brazil). An intravenous catheter was placed in the cephalic vein and $0.9 \%$ sodium chloride was administered at a rate of $5 \mathrm{~mL} \mathrm{~kg} / \mathrm{h}$ during the procedure. All radiographic and CT measurements were performed in triplicate by one experienced evaluator.

Ventrodorsal, hip-extended radiographs were obtained with a digital X-ray system (GE ${ }^{\circledR}$ Healthcare, São Paulo, Brazil). The technique used was a focal-film distance of $100 \mathrm{~cm}$ with an around $55-60 \mathrm{kV}$, and $8 \mathrm{mAs}$. The crab-eating foxes were placed in dorsal recumbency with the pelvic limbs extended caudally, held parallel, and rotated medially. The patella for each pelvic limb remained centered within the trochlear groove. The Norberg angle was calculated by the intersection of a first line drawn between the center points on each of the two femoral heads and another line drawn from the center of the femoral head to the craniodorsal acetabular rim, one to the right and the other to the left (Dennis 2012).

CT examinations were performed using a helical scanner (Shimadzu SCT-7800CT, Shimadzu Corp, Kyoto, Japan). The scanning parameters were pitch of $1.5,1 \mathrm{~mm}$ slice thickness, $120 \mathrm{kVp}, 130 \mathrm{~mA}$, and 1 -second scan time. The crab-eating foxes were maintained in a kneeling position according to previously described (Farese et al. 1998). For this, the animals were placed in sternal recumbency on a mold. The stifles were maintained in contact with the table, flexed, but not adducted.

To calculate the dorsolateral subluxation (DLS) score, the center distance (CD) index, the lateral center edge angle (LCEA), and the dorsal acetabular rim angle (DARA), the measurements obtained from transverse CT images were used, based on previously described (Kishimoto et al. 2009). The images were analyzed with ClearCanvas software (Synaptive Medical; Toronto, Canada).

To calculate the DLS score (Fig.1), initially the maximum diameter of the femoral head was measured (B). Then, two lines were established, the first line was drawn through the most lateral point of the acetabular rim and the second line was drawn through the most medial edge of the femoral head. The distance between line 1 and line 2 was measured (A). The DLS score was determined by the equation: DLS score $=\mathrm{A} / \mathrm{B} \times 100 \%$.

To determine the center distance (CD) index, the distance between the central point of the femoral head and the central point of the acetabular space (C) was first established by means of two circles (Fig.2). This distance was then divided by the radius of the femoral head (D), as follows: CD index $=C / D$.

To calculate the LCEA (Fig.3) the center points of the right and left femoral heads were initially identified. From these points two lines were drawn, the first line connected the center point of both femoral heads, and the second line connected the center point of each femoral head and the lateral point of the respective acetabular rim. The angles formed between these two lines defined the LCEAs. 
To determine the DARA three lines were drawn (Fig.4). The first line (vertically oriented) connected the caudal vertebra and the pubic symphysis, the second line was tangential to the dorsal acetabular subchondral articular surface, and the third line was drawn perpendicular to line 1 at the intersection of lines 1 and 2 . The angle formed by the intersection of lines 2 and 3 defined the DARA.

The statistical analysis of the radiographic and CT parameters initially evaluated the variability of the measurements performed in triplicate by the evaluator using repeated measures ANOVA followed by the Tukey post-test. After the distributions were evaluated by a Kolmogorov's normality test, an unpaired Student's t-test was used to compare each radiographic and CT parameter between right and left hind limbs. Differences were considered significant at $P<0.05$.

\section{RESULTS}

Signs of articular disease of the hip joint were not observed in any of the crab-eating foxes in both radiographic and CT evaluations. No statistically significant differences were observed intra-evaluator and between right and left sides in the radiographic and tomographic parameters. The measurements' mean, standard deviation, median, and confidence interval values are shown in Table 1 and 2.

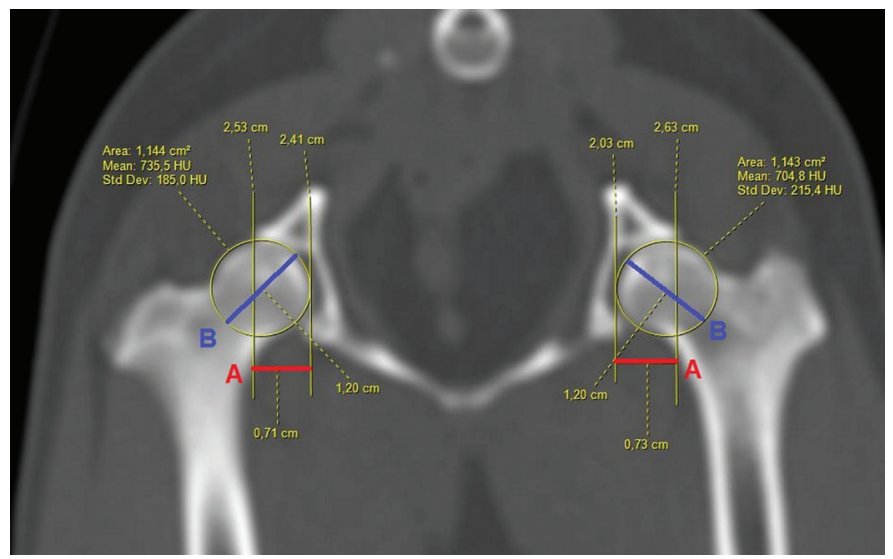

Fig.1. Transverse pelvic CT image of a crab-eating fox for measuring the Dorsolateral Subluxation (DLS) score. Maximum diameter of the femoral head (B), distance between line 1 (most lateral point of the acetabular rim) and line 2 (most medial edge of the femoral head) (A). DLS score $=\mathrm{A} / \mathrm{B} \times 100 \%$.

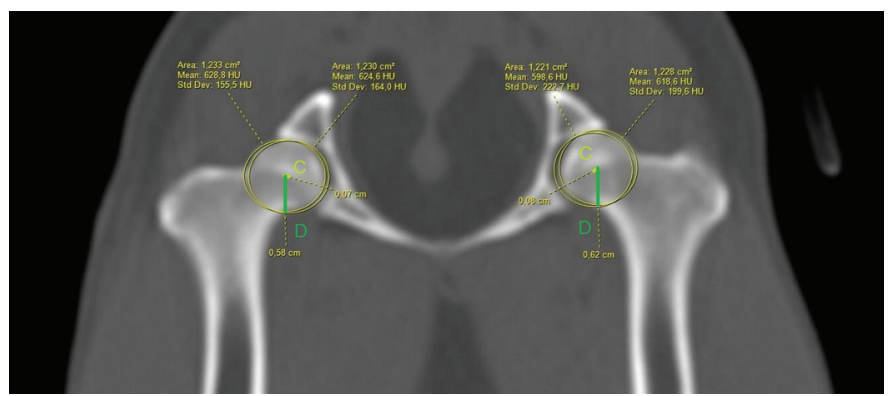

Fig.2. Transverse pelvic CT image of a crab-eating fox for measuring the Center Distance (CD) index. Distance between the central point of the femoral head and the central point of the acetabular space (C), radius of the femoral head (D). CD index = C/D.

\section{DISCUSSION}

All crab-eating foxes had no signs of hip dysplasia based on evaluations of the hip ventrodorsal extended radiographic view. Domestic dogs must be at least one year of age to be evaluated with this method, and some countries require two years of age or older to maximize the sensitivity of the method and to provide the definitive diagnosis (Adams 2000, Flückiger 2007a). Thus, the crab-eating foxes at the age of one $(n=3)$ could have not yet manifested radiographic signs of the disease. However, further studies are needed to confirm this hypothesis.

There are several systems for scoring radiographs for hip dysplasia (Schachner \& Lopez 2015). The grades of the lesion may be based on the Norberg angle, subluxation degree, shape and depth of the acetabulum, and signs of joint disease (Flückiger 2007b, Comhaire \& Schoonjans 2011). The Norberg angle is a measurement used to evaluate the femoral head displacement from the acetabulum, which in non-dysplastic domestic dogs must be greater than or equal to $105^{\circ}$ (Adams

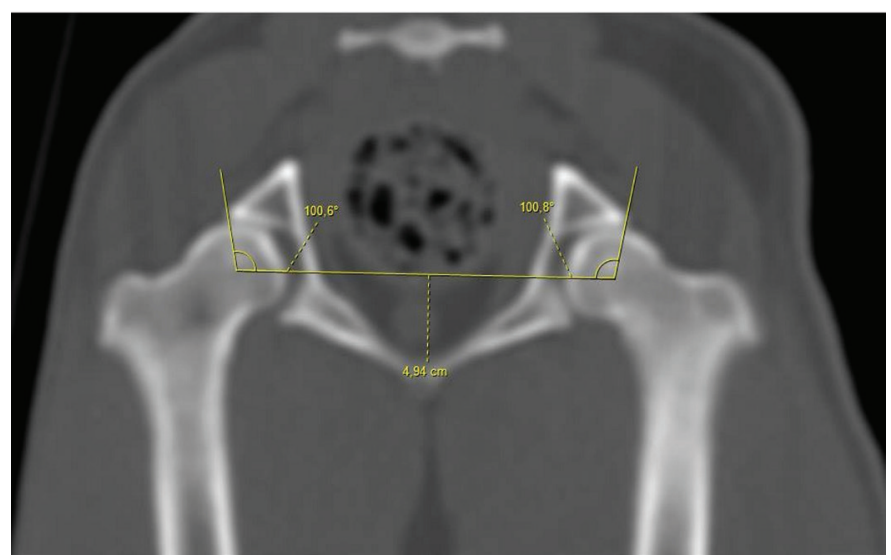

Fig.3.Transverse pelvic CT image of a crab-eating fox for measuring the lateral center edge angle (LCEA) formed for angle between line that connected the center point of both femoral heads and line that connected point of each femoral head and the lateral point of the respective acetabular rim (right $=100.6^{\circ}$, left $=100.8^{\circ}$ ).

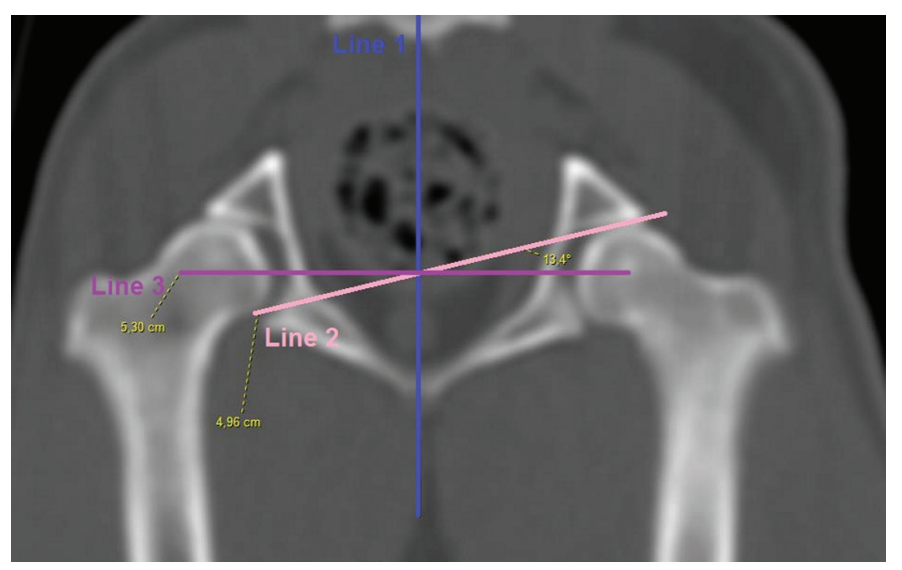

Fig.4. Transverse pelvic CT image of a crab-eating fox for measuring the dorsal acetabular rim angle (DARA). Connected caudal vertebra and pubic symphysis (Line 1), tangential to the dorsal acetabular subchondral articular surface (Line 2), perpendicular to line 1 (Line 3). DARA = angle between lines 2 and $3\left(13.4^{\circ}\right)$. 
2000, Flückiger 2007a), although some authors disagree about the validity threshold of $105^{\circ}$ for different breeds of dogs (Culp et al. 2006). In the present study, the mean Norberg angle was $107.57^{\circ} \pm 3.65^{\circ}$ that may suggest the crab-eating foxes within the normality pattern to domestic dogs.

With the advent of CT technologies, other tools for assessing hip joints have been incorporated, such as the DLS score, the CD index, the LCEA, and the DARA, which can assist in the characterization of normal and dysplastic dogs, considering joint laxity (Farese et al. 1998, Todhunter et al. 2003, Fujiki et al. 2004, Kishimoto et al. 2009). To perform these measurements, in general, the dog is placed in sternal recumbency in a kneeling position, which may be maintained in weight-bearing position with the stifles adducted, or in normal-standing position (Fujiki et al. 2004). In the current study the crab-eating foxes were in a normal-standing position.

The DLS score evaluates the passive subluxation of the hip joint by measuring the amount of the femoral head medial with respect to the acetabulum (Farese et al. 1998, Fujiki et al. 2004). Based on radiographic and CT evaluations, a study with 24 Labrador dogs suggested that a DLS score less than $40 \%$ indicates high susceptibility to osteoarthritis; less than $50 \%$ is a moderate susceptibility; and greater than $60 \%$ is unsusceptible or low susceptibility (Farese et al. 1998). On the other hand, in a study with 22 healthy Border Collie dogs mean values of $45.7 \%$ ( $\pm 10.2 \%)$ for DLS score were obtained by using CT (Kishimoto et al. 2009). The DLS score for the crabeating foxes was $60.79 \%( \pm 5.48 \%$ ), suggesting that $60 \%$ of the femoral head remained within the acetabulum. However, this value was obtained with crab-eating foxes in normal-standing position; therefore, with less load on the hip joint.

The CD index allows to measure the distance between the femoral head and the acetabulum (Fujiki etal. 2004, Kishimoto et al. 2009). In a CT study with domestic dogs, CD index values for normal hip joints were $0.17( \pm 0.1)$ and $0.22( \pm 0.07)$, respectively, in normal standing position and weight-bearing position (Fujiki et al. 2004). Similarly, in the present study, the CD index was 0.16 $( \pm 0.06)$, compatible with the positioning adopted.
A strong correlation between the DLS score $(45.7 \% \pm$ $10.2 \%)$ and the LCEA $\left(85.9^{\circ} \pm 10.3^{\circ}\right)$ was observed in a CT study with healthy Border Collie dogs, suggesting that diagnostic accuracy can be improved by combining these parameters (Kishimoto et al. 2009). The crab-eating foxes showed mean values of $60.79 \%( \pm 5.48 \%)$ and $98.25^{\circ}\left( \pm 3.87^{\circ}\right)$, respectively, for DLS and LCEA. The higher values obtained in crab-eating foxes may be associated with normal-standing position or differences between species.

In dysplastic processes, the dorsal acetabular margin is susceptible to trauma by the femoral head (Slocum \& Slocum 2014). By using the dorsal acetabular rim radiographic projection, the slope of the dorsal acetabular rim can be measured, which in domestic dogs with normal hips should be from 0 to less than $10^{\circ}$ (Wendelburg 1998, Slocum \& Slocum 2014). In turn, the value of the DARA measured by CT in healthy Border Collie dogs was $18.5^{\circ}\left( \pm 7.3^{\circ}\right.$ ), but in weight-bearing position (Kishimoto et al. 2009). In another CT study using domestic dogs of several breeds DARA $<15^{\circ}$ was obtained in normal hip joints, but laxity scores were higher in weight-bearing position than in normal-standing position, suggesting more sensitivity of the weight-bearing position (Fujiki et al. 2004). The DARA mean value was $13.47^{\circ}\left( \pm 1.04^{\circ}\right)$ in crab-eating foxes, but obtained in normal-standing position.

\section{CONCLUSION}

The data obtained are helpful in characterizing mean values of the laxity hip joint in healthy crab-eating foxes, and can contribute to the knowledge of the species.

\begin{abstract}
Acknowledgements.- The authors are grateful to "Coordenação de Aperfeiçoamento de Pessoal de Nível Superior" (CAPES), "Conselho Nacional de Desenvolvimento Científico e Tecnológico" (CNPq), protocol no. 300710/2013-5, and to the Zoological Park Foundation of São Paulo and the Municipal Zoological Park "Quinzinho de Barros” for providing the animals.
\end{abstract}

Conflict of interest statement.- The authors have no conflict of interest.

Table 1. Values of radiographic Norberg angle, and dorsolateral subluxation (DLS) score and center distance (CD) index, lateral center edge angle (LCEA), dorsal acetabular rim angle (DARA) obtained from CT images, in the right and left hind limbs, in 15 crab-eating foxes

\begin{tabular}{|c|c|c|c|c|c|c|c|}
\hline \multirow{2}{*}{ Variables } & \multicolumn{2}{|c|}{ Mean \pm Standard deviation } & \multicolumn{2}{|c|}{ Median } & \multicolumn{2}{|c|}{ 95\% confidence interval } & \multirow[t]{2}{*}{$P$ value } \\
\hline & Right & Left & Right & Left & Right & Left & \\
\hline DLS score & $59.81 \% \pm 5.24 \%$ & $61.76 \% \pm 5.64 \%$ & $60.77 \%$ & $61.45 \%$ & $56.91 \%-62.71 \%$ & $58.64 \%-64.89 \%$ & 0.3349 \\
\hline LCEA & $98.30^{\circ} \pm 3.53^{\circ}$ & $98.19^{\circ} \pm 4.20^{\circ}$ & $98.30^{\circ}$ & $97.50^{\circ}$ & $96.34^{\circ}-100.27^{\circ}$ & $95.86^{\circ}-100.53^{\circ}$ & 0.9391 \\
\hline DARA & $13.41^{\circ} \pm 1^{\circ}$ & $13.43^{\circ} \pm 0.9^{\circ}$ & $13.86^{\circ}$ & $13.70^{\circ}$ & $12.86^{\circ}-13.97^{\circ}$ & $12.92^{\circ}-13.95^{\circ}$ & 0.9611 \\
\hline
\end{tabular}

Table 2. Values of radiographic Norberg angle, and dorsolateral subluxation (DLS) score and center distance (CD) index lateral center edge angle (LCEA), dorsal acetabular rim angle (DARA) obtained from CT images, including both right and left hind limbs, in 15 crab-eating foxes

\begin{tabular}{cccc}
\hline Variables & Mean \pm Standard deviation & Median & $95 \%$ confidence interval \\
\hline Norberg angle & $107.57^{\circ} \pm 3.65^{\circ}$ & $107.35^{\circ}$ & $105.55^{\circ}-109.59^{\circ}$ \\
DLS score & $60.79 \% \pm 5.48 \%$ & $61.15 \%$ & $58.02 \%-63.56 \%$ \\
CD index & $0.16 \pm 0.06$ & 0.17 & $0.13-0.19$ \\
LCEA & $98.25^{\circ} \pm 3.87^{\circ}$ & $98.10^{\circ}$ & $96.29^{\circ}-100.21^{\circ}$ \\
DARA & $13.47^{\circ} \pm 1.04^{\circ}$ & $13.70^{\circ}$ & $12.95^{\circ}-13.99^{\circ}$
\end{tabular}




\section{REFERENCES}

Adams W.M. 2000. Radiographic diagnosis of hip dysplasia in the young dog. Vet. Clin. N. Am., Small Anim. Pract. 30(2):267-280. <https://dx.doi. org/10.1016/S0195-5616(00)50022-9><PMid:10768234>

Beisiegel B.M., Lemos F.G., Azevedo F.C., Queirolo D. \& Jorge R.S.P. 2013. Avaliação do risco de extinção do cachorro-do-mato Cerdocyon thous (Linnaeus, 1766) no Brasil. Biodiversidade Bras. 3(1):138-145.

Berta A. 1982. Cerdocyon thous. Mammalian Species (186):1-4. <https:// dx.doi.org/10.2307/3503974>

Cheida C.C., Oliveira E.M., Costa R.F., Mendes F.R. \& Quadros J. 2006. Ordem Carnivora, p.231-275. In: Reis N.R., Peracchi A.L., Pedro W.A. \& Lima I.P. (Eds), Mamíferos do Brasil. EDUEL Press, Londrina.

Comhaire F.H. \& Schoonjans F.A. 2011. Canine hip dyslasia: the significance of the Norberg angle for healthy breeding. J. Small Anim. Pract. 52(10):536-542. <https://dx.doi.org/10.1111/j.1748-5827.2011.01105.x><PMid:21967100>

Culp W.T.N., Kapatkin A.S., Gregor T.P., Powers M.Y., McKelvie P.J. \& Smith G.K. 2006. Evaluation of the Norberg angle threshold: a comparison of Norberg angle and distraction index as measures of coxofemoral degenerative joint disease susceptibility in seven breeds of dogs. Vet. Surg. 35(5):453-459. <https://dx.doi.org/10.1111/j.1532-950X.2006.00174.X><PMid:16842290>

Dennis R. 2012. Interpretation and use of BVA/KC hip scores in dogs. In Practice 34(4):178-194. <https://dx.doi.org/10.1136/inp.e2270>

Douglass E.M. 1981. Hip dysplasia in a timber wolf. Vet. Med. Small Anim. Clin. 76(3):401-403. <PMid:6908989>

Farese J.P., Todhunter R.J., Lust G., Williams A.J. \& Dykes N.L. 1998. Dorsolateral subluxation of hip joints in dogs measured in a weight-bearing position with radiography and computed tomography. Vet. Surg. 27(5):393-405. <https://dx.doi.org/10.1111/j.1532-950x.1998.tb00146.x><PMid:9749508>

Flückiger M. 2007a. How to take and read hip joint radiographs in a structured way. Eur. J. Comp. Anim. Pract. 17(2):133-134.

Flückiger M. 2007b. Scoring radiographs for canine hip dysplasia - the big three organisations in the world. Eur. J. Comp. Anim. Pract. 17(2):135-140.
Fujiki M., Misumi K. \& Sakamoto H. 2004. Laxity of canine hip joint in two positions with computed tomography. J. Vet. Med. Sci. 66(8):1003-1006. <https://dx.doi.org/10.1292/jvms.66.1003><PMid:15353857>

Ginsberg J.R. \& MacDonald D.W. 1990: South America, p.23-32. In: Ibid. (Eds), Foxes, Wolves, Jackals, and dogs. IUCN, Switzerland.

Kishimoto M., Yamada K., Paem S-H., Muroya N., Watarai H., Anzai H., Shimizu J., Iwasaki T., Miyake Y-I. \& Wisner E.R. 2009. Quantitative evaluation of hip joint laxity in 22 Border Collies using computed tomography. J. Vet. Med. Sci. 71(2):247-250. <https://dx.doi.org/10.1292/jvms.71.247> $<$ PMid:19262043>

Lucherini M. 2015. Cerdocyon thous. The IUCN Red List of Threatened Species 2015: e.T4248A81266293. Available at <http://dx.doi.org/10.2305/ IUCN.UK.2015-4.RLTS.T4248A81266293.en> Accessed on May 5, 2020.

Schachner E.R. \& Lopez M.J. 2015. Diagnosis, prevention, and management of canine hip dysplasia: a review. Vet. Med., Auckland, (6):181-192. <https:// dx.doi.org/10.2147/VMRR.S53266> <PMid:30101105>

Slocum B. \& Slocum T.D. 2014. Definitions of hip terms, p.1020-1022. In: Bojrab M.J., Waldron D.R. \& Toombs J.P. (Eds), Current Techniques in Small Animal Surgery. 5th ed. Tenton New Media, Jackson.

Todhunter R.J., Bertram J. E., Smith S., Farese J.P., Williams A.J., Manocchia A., Erb H.N., Dykes N.L., Burton-Wuster N.I. \& Lust G. 2003. Effect of dorsal hip loading, sedation, and general anesthesia on the dorsolateral subluxation score in dogs. Vet. Surg. 32(3):196-205. <https://dx.doi.org/10.1053/ jvet.2003.50035><PMid:12784195>

Verhoeven G., Fortrie R., Van Ryssen B. \& Coopman F. 2012. Worldwide screening for canine hip dysplasia: where are we now? Vet. Surg. 41(1):10-19. <https://dx.doi.org/10.1111/j.1532-950X.2011.00929.x.> $<$ PMid:23253035>

Vezzoni A. 2007. Definition and clinical diagnosis of canine hip dysplasia; early diagnosis and treatment options. Eur. J. Comp. Anim. Pract. 17:126-132.

Wendelburg K.L. 1998. Disorders of the hip joint in the canine athlete, p.174-195. In: Bloomberg M.S., Dee J.F. \& Taylor R.A. (Eds), Canine Sports Medicine and Surgery. W.B. Saunders, Philadelphia. 